\title{
Assessment of Environmental Geochemistry of Lead-Zinc Mining at Ishiagu Area, Lower Benue Trough, Southeastern Nigeria
}

\author{
Odika, P.O. ${ }^{1}$, Anike, O.L. ${ }^{1}$, Onwuemesi, A.G. ${ }^{1}$, Odika, N.F. ${ }^{1} \&$ Ejeckam, R.B. ${ }^{2}$ \\ ${ }^{1}$ Department of Geological Sciences, Nnamdi Azikiwe University, Awka \\ ${ }^{2}$ Environment Canada, Environmental Protection Operations, Winnipeg, MB. Canada \\ Correspondence: Odika, P.O., Department of Geological Sciences, Nnamdi Azikiwe University, PMB 5025 Awka, \\ Nigeria.
}

Received: October 20, 2019

Accepted: November 29, 2019

Online Published: January 5, 2020

doi:10.5539/esr.v9n1p31

URL: https://doi.org/10.5539/esr.v9n1p31

\begin{abstract}
Mining activities have long been recognized as a major source of environmental contamination associated with heavy metals and metalloids. This study evaluated the relationship between the occurrence and mining of lead-zinc sulphide ores at Ishiagu, Nigeria, and heavy metal and metalloid contamination. A comparative study of two zones in the area, with and without mining activities was also made Water, soil, stream sediment and ore samples were analyzed, after acid digestion, using atomic absorption spectrophotometer (AAS). The concentration levels of seven heavy metals and a metalloid namely $\mathrm{Pb}, \mathrm{Cu}, \mathrm{Ni}, \mathrm{Zn}, \mathrm{Mn}, \mathrm{Co}, \mathrm{Cd}$ and as were evaluated. While the highest concentration levels of $\mathrm{As}, \mathrm{Co}$ and $\mathrm{Pb}(5.20$ $\mathrm{mg} / 1,0.54 \mathrm{mg} / \mathrm{l}$ and $3.40 \mathrm{mg} / \mathrm{l}$ respectively) were found in water, those of $\mathrm{Ni}$ and $\mathrm{Mn}(2.26 \mathrm{mg} / \mathrm{l}$ and $5.48 \mathrm{mg} / \mathrm{l} \mathrm{respectively})$ occurred in soil. For $\mathrm{Cu}$ and $\mathrm{Zn}$, highest levels of concentration $(2.80 \mathrm{mg} / 1$ and $0.41 \mathrm{mg} / 1$ respectively) occurred in stream sediments. The variations in the concentration levels of these elements in varying geologic media (soil, water and sediment) indicate influence of rock types, human activities and media physiochemical characteristics. Geostatistical analyses using QQPlot, semivariogram and kriging showed normal distribution of these elements. Distribution and dispersion patterns of the heavy metals indicated increase in concentration levels in the local stream flow direction. $\mathrm{Pb}, \mathrm{Cu}$, As, $\mathrm{Cd}, \mathrm{Mn}$, and Ni concentrations had reached pollutant levels in water based on WHO standards, while $\mathrm{Zn}$ level is below. Since the local people use untreated surface water and groundwater for drinking and other domestic purposes, soil for farming and lead for cosmetics, long term exposure poses significant health risk for humans, animals and plants.
\end{abstract}

Keywords: Lead-Zinc mineralization, igneous rock quarrying, traces elements, environmental, pollution/contamination

\section{Introduction}

There is usually an interaction in the rock-water-air-life system, which gives rise to a wide range of chemical characteristics in the surface environment (Thornton, 1983). Most of these elements are essential such as $\mathrm{Mn}, \mathrm{Fe}, \mathrm{Zn}, \mathrm{Mg}$ and $\mathrm{Ca}$, while others are toxic (including $\mathrm{As}, \mathrm{Pb}$ and $\mathrm{Hg}$ ) to humans, animals, and plants (Chellan \& Sadler, 2015; Hajeb et al., 2014; Thornton, 1983; Carla, 2002; Carter \& Stewart, 2000; Chorover et al., 2007). The toxicity depends mostly on dosage, availability and accessibility. The toxic metals and metalloids have often been described as heavy, with specific gravity greater than 5.0. Examples of these metals and metalloids are $\mathrm{Pb}, \mathrm{Cd}, \mathrm{As}, \mathrm{Co}, \mathrm{Cu}, \mathrm{Zn}, \mathrm{Ni}$ and $\mathrm{Mn}$ (Edelstein \& Ben-Hur, 2018; Cooksey, 2012; Babula et al., 2008; Tamas et al., 2014). They cause environmental pollution from a number of sources. The accumulation of heavy metals in agricultural soils and water resources is of increasing concern due to food safety issues, potential health risks and contamination impacts on the ecosystems.

Lead-zinc $(\mathrm{Pb}-\mathrm{Zn})$ sulphide mining activities in the Ishiagu area in the lower Benue Trough, southeastern Nigeria have a potential significant impact on the quality of soil and water resources and, by extension, animal health and agricultural produce within the environment. Mining activities date back to the 1960s (NGSA, 2010). Previous investigations have centered largely on flotation studies (Onyemaobi, 1990), hydrometallurgy (Adebayo et al., 2003), mineralogical characterization (Olubambi et al., 2008), physicochemical properties of mine pit water (Aroh et al., 2007), geoelectric exploration (Orajaka et al., 1988) and geologic setting (Ezepue, 1984). Also, Ezepue (1985), Olubambi et al. (2008), Eze \& Uko (2003), Aroh (2003) and Aroh et al. (2006) determined the mineralogy and geochemistry of epithermal galena, siderite and trace metal status of streams receiving acid mine drainage (AMD). According to Kovacs et al. (2012), neutralized acidic mine drainage and abandoned tailing along river and stream banks pose risk of heavy metal remobilization as a secondary source of pollution. 
Previous studies suggest that $\mathrm{Pb}-\mathrm{Zn}$ ores around the study area occur at shallow depths ranging from $10 \mathrm{~m}$ to $25 \mathrm{~m}$, and mostly as open space fillings of a series of steeply dipping fractures, which cross cut the regional fold axis of the Abakaliki anticlinorium (Orajaka et al., 1988). The ores are epigenetic, massive and strata bound, and are typically formed by hydrothermal processes (Olubambi et al., 2008; Nwabufor-Ene, 1993) within the sedimentary host rocks. The deposits are hosted by carbonaceous shale and contain mostly Fe, Al, Mg, Si, S, Zn, Cu, Ni, Cd, Co, Mn, Pb and As. The mineralization comprises massive sulfides containing mainly sphalerite, galena, siderite, quartz and traces of pyrite and copper bearing minerals (Oha et al., 2017; Ezepue, 1984). Although there have been several geophysical, quantitative and chemical studies of the deposits (Adebayo et al., 2003; Olubambi et al., 2008; Orajaka et al., 1988, Ezepue, 1984, Aroh et al., 2006), the concentration distribution pattern of contaminants and potential impacts of abandoned mines and mine wastes are yet to be adequately assessed and addressed (Aroh, et al., 2006, 2007, Foley, 2002, 2011, Cidu, 2002, 2007, 2009, Aroh, 2003).

Further, proper environmental regulations and enforcement for mining activities are not well promoted. In addition, loss of lives and property resulting from mining activities have not been properly documented or addressed by the relevant authorities. Chemical contamination or pollution of water and soil systems at both abandoned and active mining sites demands rigorous investigation and proper attention. For instance, Mejia (2015) reported that in 2010, Zamfara State in northern Nigeria witnessed lead poisoning from artisanal gold mining, with an average concentration in the local river as high as $1270 \mathrm{mg} / \mathrm{l}$. This resulted in the death of more than 300 people, who were mostly artisans, including children, youth and women. Other environmental concerns involve the effect of extensive past magmatic activities and the occurrence of intrusive and extrusive rocks in the Benue Trough (Etuk et al., 2008). These igneous rocks occur over a distance of $500 \mathrm{~km}$ from Ishiagu in the Lower Benue Trough to Zurak in the Upper Benue Trough with the number of occurrences increasing from Zurak towards the south (Ezepue, 1984, Etuk et al., 2008). Obiorah \& Umeji (1995) noted that there was emplacement of numerous mafic intrusive and alkaline/calc-alkaline lava and tuffs associated with the Santonian deformation. The Ishiagu area is characterized by both commercial and artisanal mining and quarrying. The current mining methods are open-pit, involving the excavation of large quantities of host rock in order to extract the desired ore. The ore is processed by pulverization and flotation and the concentrates are usually shipped to smelters locally or exported overseas. The local population also extracts these deposits for domestic purposes such as cosmetics or medical. In addition, artisanal quarrying of igneous rock avail the locals with aggregates for domestic use and local trading. These activities have over a long period served many in the community and visitors as a means of livelihood.

In this work, two areas Ishiagu and Iheututu were studied. This paper presents the results of environmental geological and geochemical studies conducted around mining and quarry sites within these zones to assess the effects of these activities. Elements concentration levels in different media with respect to mining and quarrying sites demand investigation. A combination of geological, geochemical and petrographic data can reveal the source, nature and extent of elements concentrations (Mielka et al., 2000, Facchinelli et al., 2001, Dold, 2005). The methods employed for this study are capable of identifying the sources of contaminants and pollutants. The study will also establish baseline data for soil, stream sediment and surface and groundwater for the area against which future research results could be measured.

\section{Study Area}

The study area lies between latitudes $5.52-6.00 \mathrm{~N}$ and longitudes $7.30-7.36 \mathrm{E}$ (Figure 1). Locally, the relief is undulating with rolling hills and hillocks that rise up to $93 \mathrm{~m}$ above sea level. Egboka \& Uma (1986) and Hall \& Medler (1975) observed that the climatic setting is as varied as savannah conditions in the northern part with stunted trees, derelict woodland, few shrubs and dispersed large trees, and the tropical rain forest in the south with luxuriant evergreen trees. The rain forest vegetation is dominant. There are two major seasons; the wet season (from March to October) and the dry season (from October to February/March). These seasons arise from the two prevailing winds at different periods of the year; the dry harmattan wind from the Sahara desert and the marine wind from the Atlantic Ocean. The temperature ranges from $20^{\circ}$ to $38^{\circ} \mathrm{C}$ in the dry season and from $16^{\circ}$ to $28^{\circ} \mathrm{C}$ in the rainy season. 


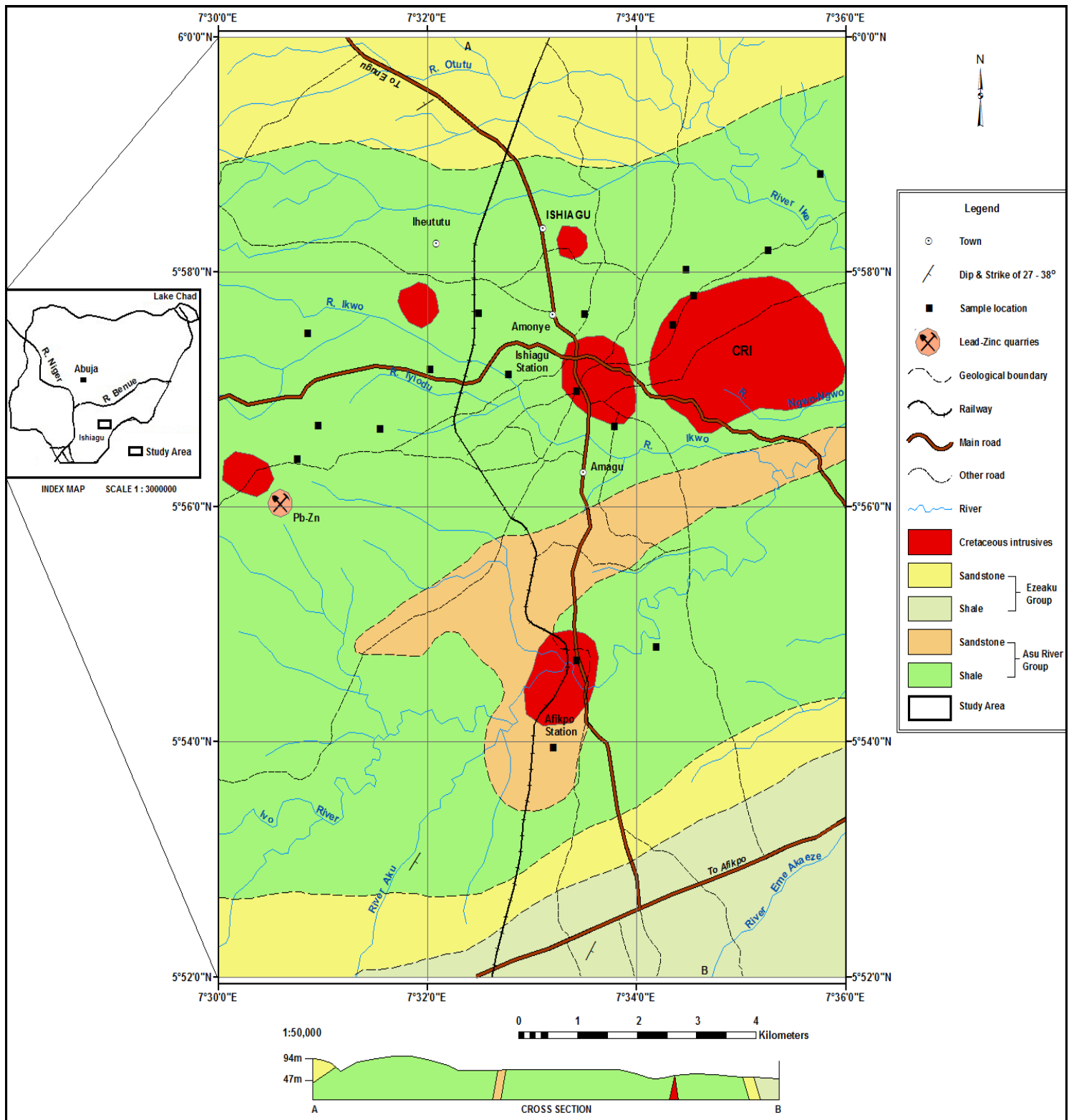

Figure 1. Geological and location map of the study area, inset is map of Nigeria with a black box showing the study area (modified after Oha, 2017)

The area is predominantly underlain by the shale of the Asu River Group of the Albian age (Figure 2). The shale grades unconformably into the younger sequence of sandstone and shale units of the Eze-Aku Formation of Late Cenomanian-Turonian age. Field observations show epigenetic massive sulphide ore deposits hosted by folded and faulted shales. The shales are predominantly black or dark grey, finely laminated and fissile. They are associated with intrusive igneous rocks. The younger sandstone unit of the Eze-Aku Formation underlies the northern and southern parts of the area. This unit is generally greyish white (turned brown by weathering), fine-grained and poorly sorted. It strikes ENE - NE with dips of $27^{\circ}-38^{\circ} \mathrm{NW}$ and SE, and rest uncomformably on the Albian Asu River shale. The shale unit of the Eze-Aku Formation is grey, carbonaceous, thinly to thickly bedded, flaggy and fissile on weathering.

The ore deposits in the study area and elsewhere in the Benue Trough have been analysed by previous workers. Northeast of the study area the ores comprise predominantly $\mathrm{Pb}-\mathrm{Cu}-\mathrm{Mn}-\mathrm{Ni}$ sulfides, whereas, those in the southwest area show strong enrichment of Pb-Zn-As. Ezeh (2007), reported that in Enyigba and Abakaliki areas (close to the study area), ores contain predominantly $\mathrm{Pb}-\mathrm{Zn}$ sulfides, while in Uburu and Okposi zones (also close to the study area), the ores are dominated by mostly $\mathrm{Cu}$-rich sulfides. The simple sulfide mineral assemblages of Ishiagu ore deposits consist of galena, 
sphalerite, pyrite, marcasite and chalcopyrite. Combined lead plus zinc grades in Ishiagu deposits may constitute up to $15 \%$ of the veins, while siderite may be present up to $80 \%$ and quartz 5\% (Olubambi et al., 2008, Okafor \& Uwadiale, 1997 , Ezepue, 1984). Trace amounts of other sulphide and sulfosalt minerals make up the balance. Within a given lead-sulphide lode, mineralogy of the individual deposit may be quite variable. Secondary minerals of the ores are anglesite, smithsonite, cerrusite, malachite, sulfur, gypsum, hydrous iron oxide minerals, hematite, greenockite, Malachite and azurite (Olubambi et al., 2008).

It should be noted that the local population has worked these deposits for domestic uses, while numerous mining companies have extracted some of the ores for commercial purposes, starting from 1962 up to the present. Other long term existing land use activities include rock quarrying (both commercial and artisanal), farming and local herding.

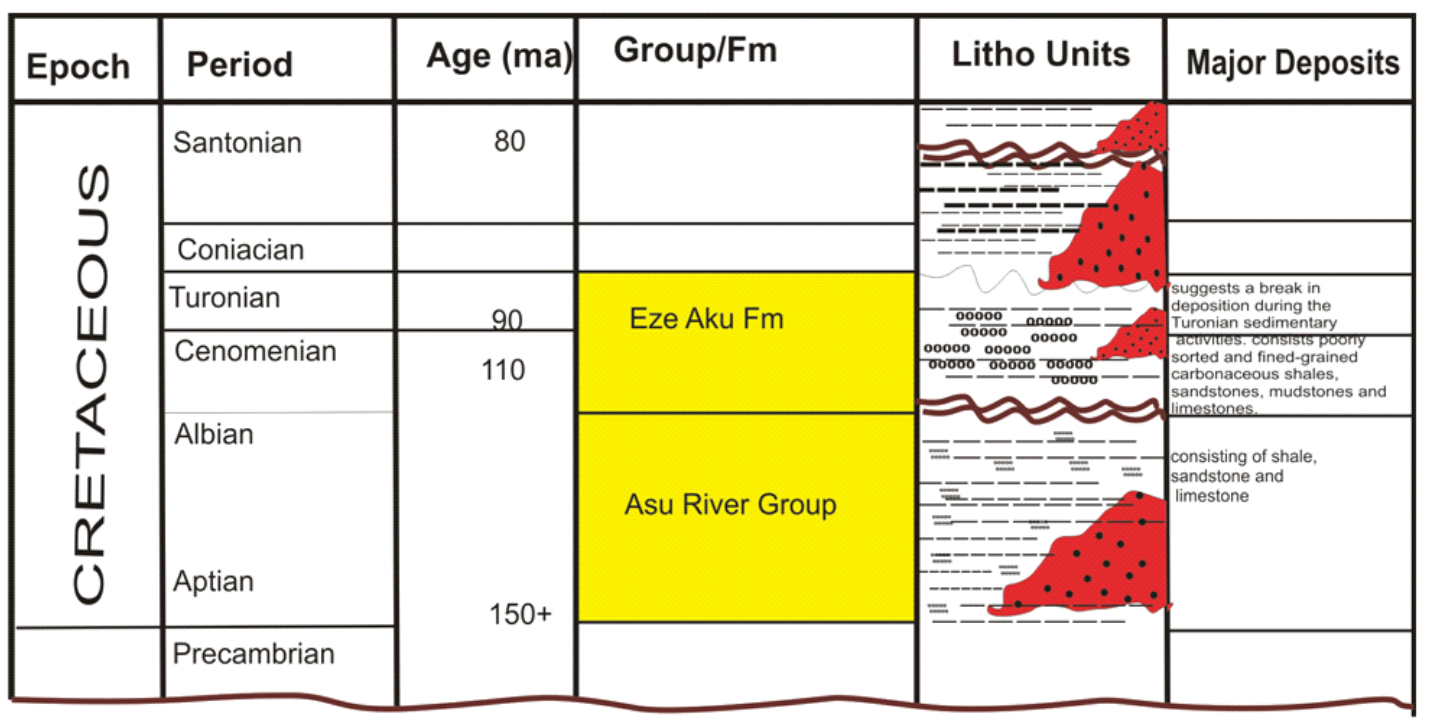

Figure 2. Lithostratigraphic succession of part of the southern Benue Trough covering the study area (boxes in yellow are the formations found in the study area)

\section{Material and Methods}

Twenty-six out of a total number of thirty-six samples were analysed; eleven samples from water, six samples from soil, three stream sediment samples, three tailing samples and three igneous rock samples. Samples were collected widespread in the study area and as dictated by locations of water sources, mineralizations and intrusives, including from around an ore mining site and an igneous rock quarry. Sample collection, preservation and chemical analyses were done based on modern methods for environmental sample preparation and analysis according to Santelli et al. (2004).

\section{Collection and preparation of samples}

Water samples were collected from streams, rivers, a spring, a hand-dug well and boreholes to assess the concentration levels of contaminants in different environmental media. For each sample, about $250 \mathrm{ml}$ was collected in hard polyethylene bottles. The bottles were cleaned using metal-free $0.1 \mathrm{M} \mathrm{HNO} 3$, and rinsed thoroughly with the sample water at the point of collection. Values of the $\mathrm{pH}$, temperature, TDS, and conductivity were determined and recorded in the field. The samples were refrigerated at $4 \mathrm{oC}$ and analyzed within four (4) days of collection in accordance with standard specifications (Santelli et al., 2004). Soil samples were collected from the bottom of holes $5 \mathrm{~cm}$ to $25 \mathrm{~cm}$ deep depending on location and induration, using plastic picks and trowels. Stream sediment samples were collected from river and stream beds using an auger. At each location, about $100 \mathrm{~g}$ of fine fractions were collected and labeled. The damp stream sediment and soil samples were air dried for three days. Sun or oven drying was not used in order to prevent chemical reactions or decomposition of elements or compounds.

\section{Analysis of samples}

The dried samples were further disaggregated (with agate mortar) and sieved to $150 \mu \mathrm{m}$ size fraction (using non-metallic Endecotts electronic shaker, M-073038). $1.0 \mathrm{~g}$ of well mixed sample, weighed with Mettler Toledo MPL 203, of each was digested using $10 \mathrm{ml}$ of aqua regia, $5 \mathrm{ml}$ of $\mathrm{HF}$ and $25 \mathrm{ml}$ of boric acid solution. The analytes were further filtered and analyzed for total metal concentrations of $\mathrm{Pb}, \mathrm{Zn}, \mathrm{Cd}, \mathrm{Co}, \mathrm{Cu}, \mathrm{As}, \mathrm{Mn}$, and $\mathrm{Ni}$ using the AAS. Sample decomposition was done to bring the analyte concentrations of the solid samples within the working range of the analytical technique selected 
(AAS); that is, to aid the reduction of chemical manipulation in scale and complexity, and for minimal quantities of reagents to be used. Thus, $100 \mathrm{ml}$ of well mixed sample each was mixed with $20 \mathrm{ml}$ of aqua regia $\left(\mathrm{HNO}_{3}(150 \mathrm{ml})\right)+\mathrm{HCl}$ $(450 \mathrm{ml})$ ), deionised water $+25 \mathrm{ml} \mathrm{H}_{3} \mathrm{BO}_{3}$ and $5 \mathrm{ml} \mathrm{HF}$ ) to keep the elements in analytic state. Hydrofluoric acid was added to dissolve any suspended and siliceous material (such as $\mathrm{Ca}, \mathrm{Si}$ ) and boric acid to neutralize the HF. The solutions were filtered and further analyzed to determine total metal concentrations of some selected heavy metals using the AAS, Buck Scientific 210VGP. Standard wavelengths used for $\mathrm{Pb}, \mathrm{Zn}, \mathrm{As}, \mathrm{Cd}, \mathrm{Cu}, \mathrm{Ni}, \mathrm{Co}$ and $\mathrm{Mn}$ were $283.3 \mathrm{~nm}, 307.6 \mathrm{~nm}, 331.8 \mathrm{~nm}$, $326.1 \mathrm{~nm}, 327.4 \mathrm{~nm}, 341.5 \mathrm{~nm}, 352.7 \mathrm{~nm}$ and $279.5 \mathrm{~nm}$ respectively. The wavelength accuracy and detection limit of the analyses were $\pm 0.2 \mathrm{~nm}$ and $0.01 \mu \mathrm{g} \mathrm{ml}^{-1}$ respectively according to ISO 26845:2008 and ICH 2000. Other parameters measured both in the field and laboratory include $\mathrm{pH}$, temperature, total dissolved solid (TDS), and electrical conductivity (EC). In addition, petrographic microscope studies on thin sections were conducted on the igneous rock samples according to ASTM C1721, Standard Guide. For petrographic study, instrumentation analysis was done using Hillquist Thin Section Machine, Model 1005 \& 1010 and Olympus petrological microscope. While sample preparations were carried out at the Departments of Geology, Civil Engineering, Biochemistry and Industrial Chemistry at the Nnamdi Azikiwe University, Awka, AAS analysis was conducted at the Projects Development Institute (PRODA), Federal Ministry of Science and Technology, Enugu, and petrographic studies were done at the Geology Department, Kogi State University, Aigba, all in Nigeria.

\section{Results and Discussion}

Geochemical analysis of soil, stream sediments, groundwater, surface water and ores were conducted to determine concentrations of $\mathrm{Pb}, \mathrm{Zn}, \mathrm{Cu}, \mathrm{Cd}, \mathrm{Ni}, \mathrm{Co}, \mathrm{Mn}$, and As. The results are shown in Tables 1-4. The results reveal that the highest total concentration of heavy metals observed within the area were: for $\mathrm{Cu}: 2.80 \mathrm{mg} / \mathrm{l}, \mathrm{Zn}: 0.82 \mathrm{mg} / \mathrm{l}, \mathrm{As}: 5.20 \mathrm{mg} / \mathrm{l}$, Cd: $0.33 \mathrm{mg} / \mathrm{l}, \mathrm{Ni}: 2.26 \mathrm{mg} / \mathrm{l}$, Co: $0.54 \mathrm{mg} / \mathrm{l}$, and Pb: $3.40 \mathrm{mg} / \mathrm{l}$ (Table 1). According to the World Health Organization (WHO 2004, 2011) guidelines for drinking water quality, acceptable selected elements concentrations are: for Cd: 0.003 mg/l, As: $0.01 \mathrm{mg} / 1, \mathrm{Mn}: 0.4 \mathrm{mg} / \mathrm{l}, \mathrm{Ni}: 0.07 \mathrm{mg} / \mathrm{l}, \mathrm{Pb}: 0.01 \mathrm{mg} / \mathrm{l}, \mathrm{Cu}: 2 \mathrm{mg} / \mathrm{l}, \mathrm{Zn}: 5 \mathrm{mg} / \mathrm{l}, \mathrm{Co}: 0.05 \mathrm{mg} / \mathrm{l}$. This study shows that $\mathrm{Pb}, \mathrm{Cd}, \mathrm{As}$, and $\mathrm{Ni}$ concentrations in water sources are above the acceptable level for drinking water quality and hence, are potential pollutants. Most of Co concentration levels in water sources are within the WHO standard for drinking water, except those around the $\mathrm{Pb}-\mathrm{Zn}$ mining site within the Iheututu area. The results also show that concentration levels of heavy metals and metalloid are generally higher in surface and groundwater samples than samples from other media. $\mathrm{Mn}$ shows highest concentration in the soil whereas $\mathrm{Cu}$ shows highest concentration in the stream sediment. As shows highest concentration in groundwater, followed by $\mathrm{Pb}$ and $\mathrm{Ni}$.

Table 1. Results of water analysis for Ishiagu area

\begin{tabular}{|c|c|c|c|c|c|c|c|c|c|c|c|}
\hline Location & 1 & 2 & 3 & 4 & 5 & 6 & 7 & 8 & 9 & 10 & 11 \\
\hline Temperature $\left({ }^{\circ} \mathrm{C}\right)$ & 28.7 & 27.3 & 31.0 & 30.5 & 30.2 & 28.7 & 38.0 & 28.0 & 29.0 & 29.3 & 27.1 \\
\hline pH & 6.05 & 5.00 & 6.28 & 6.36 & 6.25 & 6.35 & 7.07 & 6.63 & 6.57 & 6.95 & 5.77 \\
\hline TDS (calculated) & 170 & 20 & 40 & 100 & 60 & 50 & 20 & 40 & 390 & 1270 & 230 \\
\hline $\mathrm{EC}(\mu \mathrm{s} / \mathrm{cm})$ & 254 & 30 & 60 & 149 & 90 & 75 & 30 & 60 & 583 & 1896 & 343 \\
\hline \multicolumn{12}{|l|}{ Constituents (mg/l) } \\
\hline Copper $(\mathbf{C u})$ & 0.40 & 1.20 & 0.90 & $<0.10$ & 0.60 & 1.10 & 0.30 & 1.60 & 0.70 & $<0.10$ & 0.10 \\
\hline Zinc (Zn) & $<0.10$ & 0.24 & 0.25 & 0.25 & 0.07 & 0.82 & 0.04 & 0.24 & 0.07 & $<0.10$ & 0.30 \\
\hline Arsenic (As) & $<0.10$ & 0.80 & 3.00 & 3.00 & 2.60 & 4.00 & 5.20 & 2.90 & 0.80 & 1.70 & 2.20 \\
\hline Cadmium (Cd) & 0.04 & 0.18 & 0.10 & 0.18 & 0.22 & 0.05 & 0.14 & 0.23 & 0.01 & 0.13 & 0.19 \\
\hline Nickel (Ni) & 0.60 & 0.29 & 0.48 & 1.10 & 1.11 & 0.26 & 0.30 & 0.44 & 1.70 & $<0.10$ & 1.15 \\
\hline Cobalt (Co) & 0.03 & 0.01 & 0.05 & 0.08 & 0.54 & 0.09 & 0.04 & 0.01 & 0.06 & 0.01 & 0.06 \\
\hline Lead (Pb) & 1.10 & 1.10 & 0.80 & 1.20 & 3.00 & 0.10 & 0.60 & 1.10 & 3.40 & 0.10 & 2.00 \\
\hline
\end{tabular}

Locations: 1 = Ngwongwo; 2 = Amaeze Plaza Hotel 1; 3 = Amagu Ikwo; 4 = Iheututu Iyiodu; 5 = Iheututu Ikwo; $6=$ Iheututu 1; 7 = Iheututu 2; 8 = Amagu Ivo; $9=$ Amaokwe Borehole; $10=$ Ngwongwo CRI; $11=$ Amaeze Plaza Hotel 2. 
Table 2. Result of soil analysis for Ishiagu town

\begin{tabular}{|c|c|c|c|c|c|c|}
\hline Location & $\mathbf{9 a}$ & $9 b$ & 6 & 7 & 8 & 12 \\
\hline Depth Horizon (cm) & 15 & 7 & 10 & 5 & 7 & 8 \\
\hline \multicolumn{7}{|l|}{ Constituents (mg/l) } \\
\hline Copper $(\mathbf{C u})$ & 0.60 & 0.60 & 0.40 & 0.60 & 0.20 & 0.10 \\
\hline Zinc $(Z n)$ & $<0.10$ & 0.27 & 0.07 & $<0.10$ & 0.07 & 0.16 \\
\hline Manganese (Mn) & 2.23 & $<0.10$ & 5.84 & $<0.10$ & $<0.10$ & 2.68 \\
\hline Cadmium (Cd) & $<0.10$ & 0.06 & 0.09 & 0.010 & 1.40 & 0.69 \\
\hline Nickel (Ni) & 2.26 & 0.62 & 0.15 & $<0.10$ & 1.40 & 0.69 \\
\hline Cobalt (Co) & $<0.10$ & 0.03 & 0.10 & 0.08 & 0.02 & 0.09 \\
\hline Lead $(\mathbf{P b})$ & 0.30 & $<0.1$ & 1.10 & 0.10 & 1.10 & $<0.10$ \\
\hline Arsenic (As) & $<0.10$ & $<0.10$ & $<0.10$ & $<0.10$ & $<0.10$ & $<0.10$ \\
\hline
\end{tabular}

Locations: 9a = Amaokwe CRI; $9 b=$ Amaokwe CRI Intrusives; $6=$ Iheututu 1; 7 = Iheututu 2; $8=$ Amagu Ivo; $12=$ Amaonye.

Table 3. Results of stream sediment analysis for Ishiagu town

\begin{tabular}{llll}
\hline Location & 1a & $\mathbf{1 3}$ & $\mathbf{4 a}$ \\
\hline Constituents (mg/l) & & & \\
Copper (Cu) & 2.80 & 1.00 & $<0.10$ \\
Zinc (Zn) & 0.12 & 0.41 & $<0.10$ \\
Manganese (Mn) & $<0.10$ & $<0.10$ & $<0.10$ \\
Cadmium (Cd) & 0.13 & 0.06 & 0.07 \\
Nickel (Ni) & 1.50 & 0.54 & 1.34 \\
Cobalt (Co) & 0.02 & $<0.10$ & 0.05 \\
Lead (Pb) & 0.80 & 1.20 & 0.70 \\
Arsenic (As) & $<0.10$ & $<0.10$ & $<0.10$ \\
\hline
\end{tabular}

Locations: $1 a=$ Ngwongwo; $13=$ Ike River; $4 a=$ Iheututu Iyiodu

Table 4. Results of tailing analysis for $\mathrm{Pb}-\mathrm{Zn}$ mine tailings Ihetutu area. $\mathrm{TS}=$ Tailings sample

\begin{tabular}{llll}
\hline Location & \multicolumn{2}{l}{ Iheututu Pb-Zn mine } & TS3 \\
\hline $\begin{array}{l}\text { Sample code number } \\
\text { Constituents (mg/l) }\end{array}$ & TS 1 & TS2 & \\
Copper (Cu) & 0.20 & 0.10 & 1.10 \\
Zinc (Zn) & 0.08 & 0.37 & 0.06 \\
Arsenic (As) & 0.09 & $<0.10$ & 0.20 \\
Cadmium (Cd) & 0.33 & 0.14 & 0.12 \\
Nickel (Ni) & 0.87 & 0.64 & 0.08 \\
Cobalt (Co) & 0.08 & $<0.10$ & 0.03 \\
Lead (Pb) & 0.50 & 0.00 & 1.70 \\
\hline
\end{tabular}

\subsection{Geochemical Analysis}

A combination of statistical and geostatistical analysis was applied in processing, analyzing, interpreting and discussing the results. This process involved application of QQPlot, semivariogram and kriging interpolation of contaminants in samples from water medium. Water medium was selected due to its wider distribution and sample representation within the study area.

Statistical analysis of distribution normality of contaminants was conducted. As normally distributed data is expected to plot as a straight line (Zhang, 2006, Masi \& Mogan, 2005, Bohling, 2005), the QQPlots to assess normality of Cu, Zn, Cd, $\mathrm{As}, \mathrm{Ni}, \mathrm{Co}$ and $\mathrm{Pb}$ in water medium, clearly show normal distribution (Figure 3 ). 

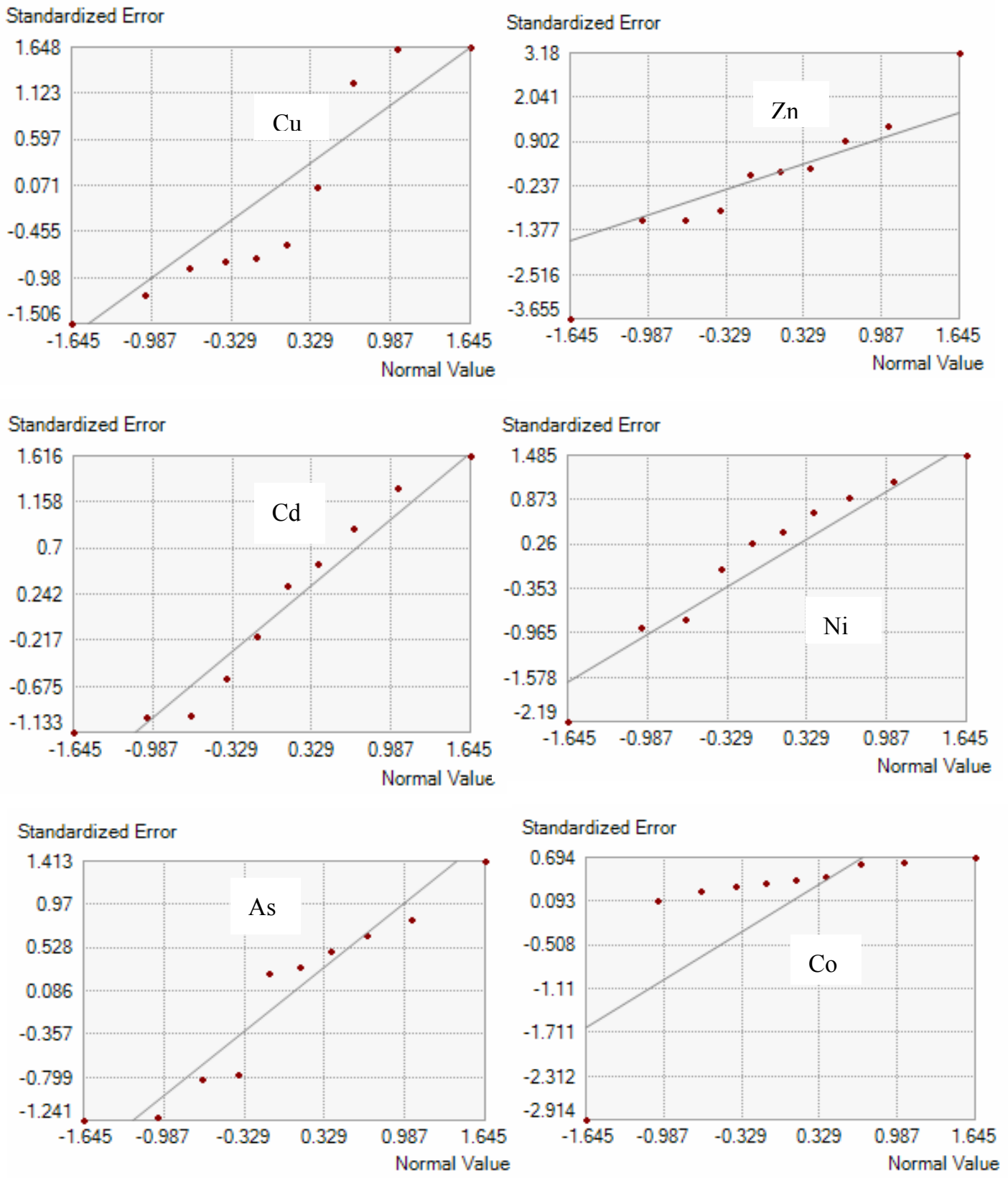

\section{Standardized Error}

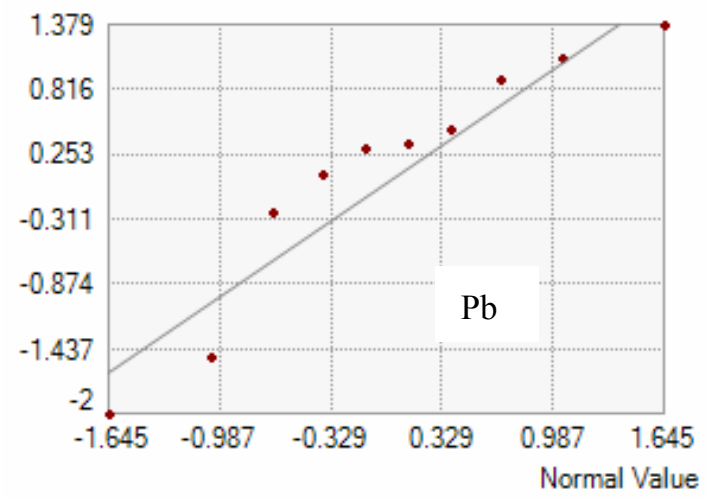

Figure 3. Normal QQPlots showing normality of contaminants concentration distribution except Co 
From the above plots, Co QQPlot line deviate from $45^{\circ}$ and are not very close to being straight, indicating non-lognormal distribution of contaminant. Other elements show normal distribution. Evaluation of spatial semivariance of contaminants concentration pairs with respect to their sample location distances shows mostly Stable Model semivariogram with plume (equidimensional) structure (Figure 4). While majority of the contaminants indicate near zero (0) nugget effect, Pb however, exhibits above one (1) nugget value (Table 5). Generally, there is a spatial correlation of homogeneity at distances larger than the typical sample spacing, without trend of variation, thus, indicating natural ore deposit as primary source of contaminants. The nugget effect can be attributed to a number of factors including the source soil/rock type, environmental mobility effect on elements and impacts of human activities. Taking $\mathrm{Pb}$ into consideration, the nugget effect indicates that both natural and anthropogenic factors could have influenced the near even distribution of this contaminant within certain locations of the study area. Anthropogenic activities such as borehole drilling (as observed at Amaokwe) through $\mathrm{Pb}$ deposit can trigger migration of $\mathrm{Pb}$ from its natural source (ore deposit) into the aquifer system. Similarly, the sills of the contaminants reflect blancket nature, with $\mathrm{Cu}, \mathrm{Zn}$ and $\mathrm{As}$ having sill values of above 1 , and show more concentration levels within common location range than $\mathrm{Cd}, \mathrm{Ni}, \mathrm{Co}$ and $\mathrm{Pb}$.
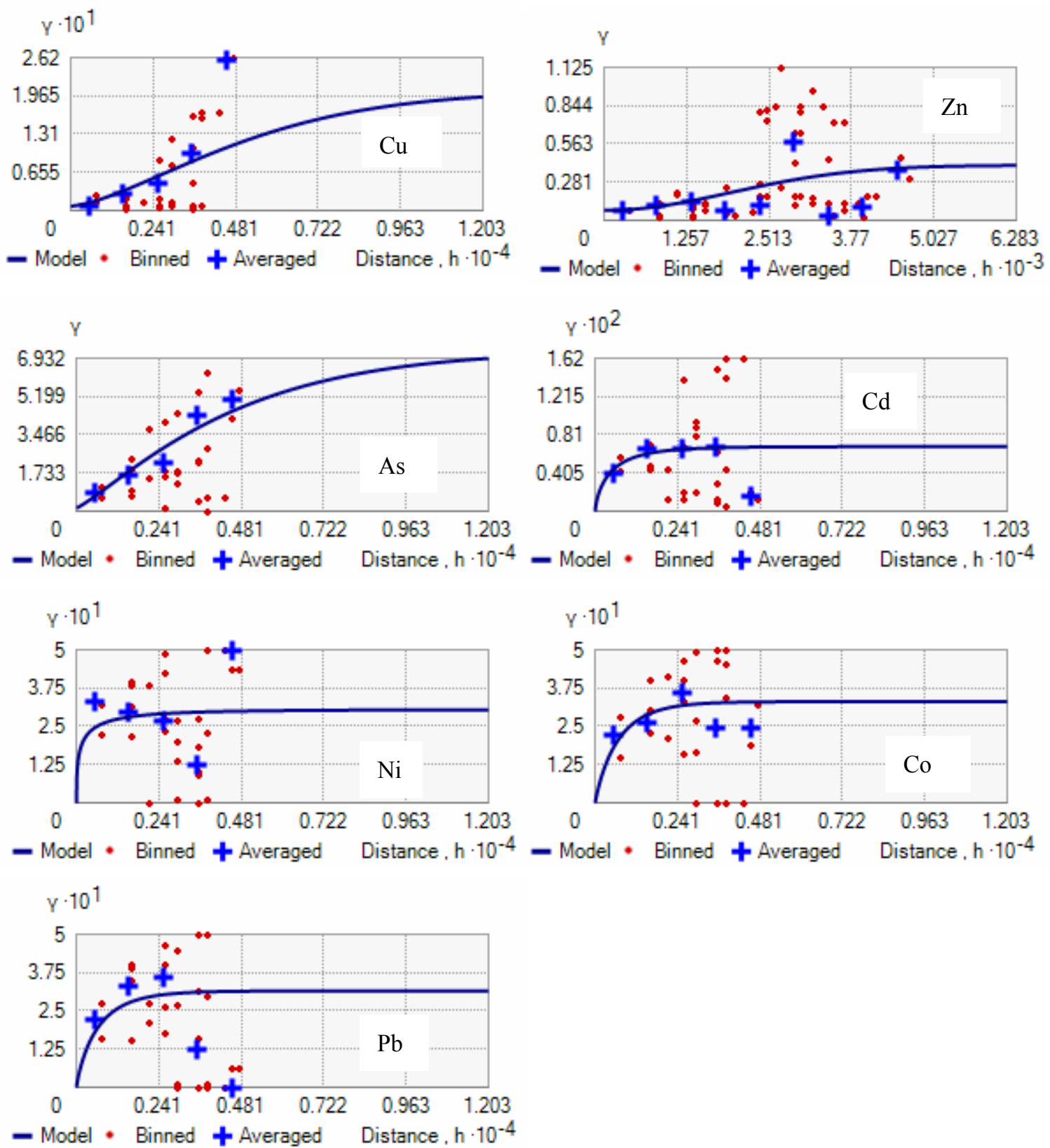

Figure 4. Plots showing semivariogram results of contaminants 
Table 5. Semivariogram parameters

\begin{tabular}{l|l|l|l|l|l|l}
\hline Parameter & Model type & Lag size/No of lag & Nugget & Partial sill & Sill & Range \\
\hline $\mathrm{Cu}$ & Stable & $523 / 12$ & 0.07 & 0.33 & 2.0 & 4701 \\
\hline $\mathrm{Zn}$ & Stable & $1002 / 12$ & 0.01 & 0.20 & 1.5 & 12034 \\
\hline $\mathrm{As}$ & Stable & $1002 / 12$ & 0.16 & 7.12 & 1.2 & 12034 \\
\hline $\mathrm{Cd}$ & Stable & $1002 / 12$ & 0.00 & 0.01 & 0.7 & 2312 \\
\hline $\mathrm{Ni}$ & Stable & $1002 / 12$ & 0.24 & 0.00 & 0.2 & 12034 \\
\hline $\mathrm{Co}$ & Stable & $1002 / 12$ & 0.03 & 0.00 & 0.2 & 12034 \\
\hline $\mathrm{Pb}$ & Stable & $1002 / 12$ & 1.23 & 0.00 & 0.2 & 12034 \\
\hline
\end{tabular}

The Ordinary Kriging (OK) method, among the many different kriging techniques, was used in this study due to its simplicity and prediction accuracy when compared with other kriging methods (Issaks \& Srivastava, 1989, ESRI, 2010). Ordinary Kriging non-stationary conditions were taken into account by limiting the domain of stationarity to a local neighbourhood and moving it across the study area. After normalization of data for interpolation of some selected heavy metals and metalloid, kriging techniques were used to predict spatial distribution of these metals and metalloid. A variogram was further drawn to select suitable model for fitness on experimental variogram using Less Mean Standardized (MS) value, while best interpolation method was selected using cross-validation and Root Mean Square Standardized (RMSS), as shown in Table 6. GIS (ESRI) ArcMap 10.3.1 was further used to produce geochemical maps (Fig. 5a - h) of heavy metals and metalloid based on this interpolation. The directional influence and trend analysis of geochemical maps from kriging surfaces depict hot-spots of contaminants in the northeast direction. Considering the northwest-southeast flow direction of river distributaries in the area and abundance of igneous rock intrusives associated with hydrothermal deposits (Olubambi et al., 2008, Obiorah \& Umeji, 1995) majorly in the northeast area of the site, the folded and faulted anticline features trending northeast with dips of $18^{\circ}-36^{\circ}$ to the northwest and southeast, the indication is a more natural source than anthropogenic contaminant source.

Table 6. Prediction errors - fitted parameters of the variogram models for heavy metals and metalloid in water samples

\begin{tabular}{l|l|l|l|l|l}
\hline \multirow{2}{*}{ Parameter } & \multicolumn{4}{|l}{ Prediction error } & \multicolumn{4}{l}{} \\
\cline { 2 - 6 } & Mean & RMS & ASE & MS & RMSS \\
\hline $\mathrm{Cu}$ & -0.16 & 0.5 & 0.39 & -0.08 & 1.13 \\
\hline $\mathrm{Zn}$ & -0.03 & 0.3 & 0.16 & -0.09 & 1.7 \\
\hline $\mathrm{As}$ & -0.01 & 0.9 & 1.14 & -0.01 & 0.88 \\
\hline $\mathrm{Cd}$ & 0.01 & 0.07 & 0.08 & 0.08 & 0.95 \\
\hline $\mathrm{Ni}$ & 0.05 & 0.55 & 0.52 & 0.10 & 1.06 \\
\hline $\mathrm{Co}$ & 0.01 & 0.17 & 0.16 & 0.08 & 1.01 \\
\hline $\mathrm{Pb}$ & 0.11 & 1.22 & 1.18 & 0.09 & 1.03 \\
\hline
\end{tabular}

Where RMS = root mean square; ASE = average standard error; $\mathrm{MS}=$ mean standardized and RMSS = root mean square standardized. 

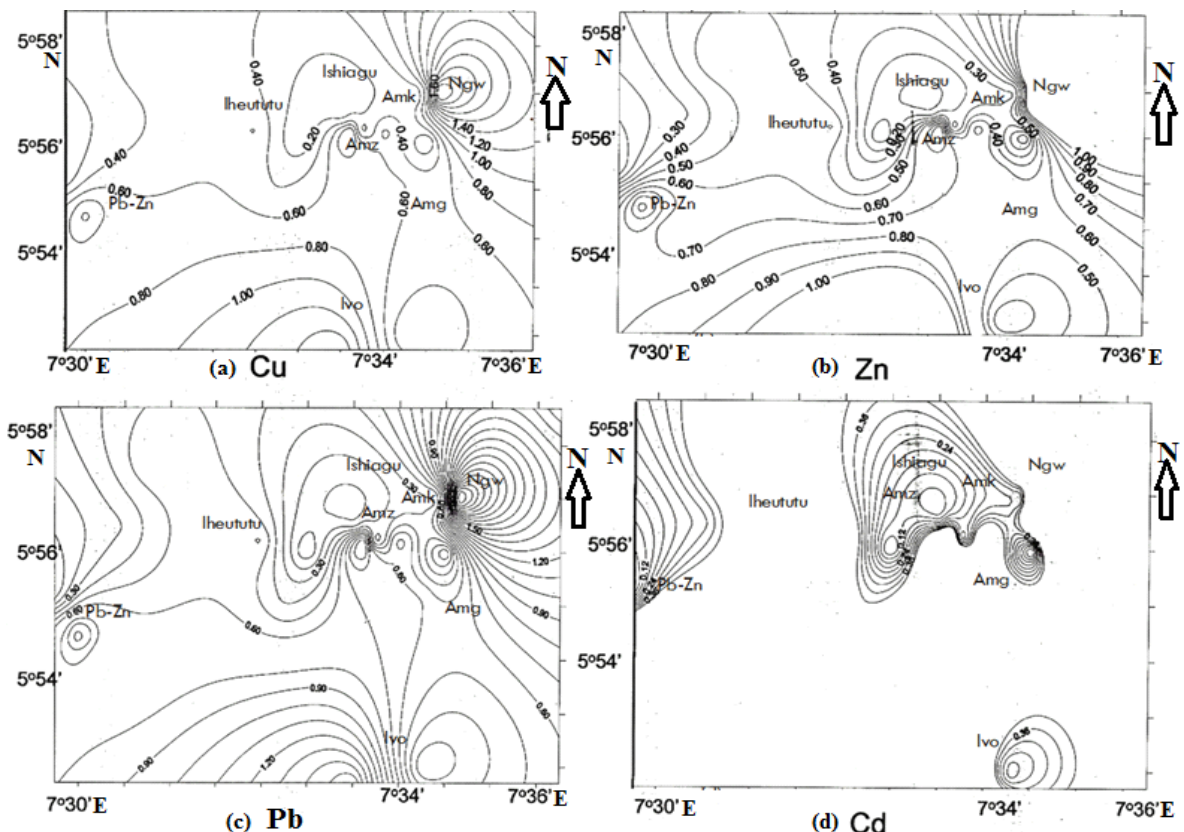

Figure 5 (a-d). Geochemical maps of some selected heavy metals in rock, soil, and water and stream sediment media in Ishiagu town showing dispersion and distribution patterns of the elements. Ngw $=$ Ngwongwo, Amk $=\mathrm{Amaokwe}, \mathrm{Amg}=$ Amagu, Amz = Amaeze
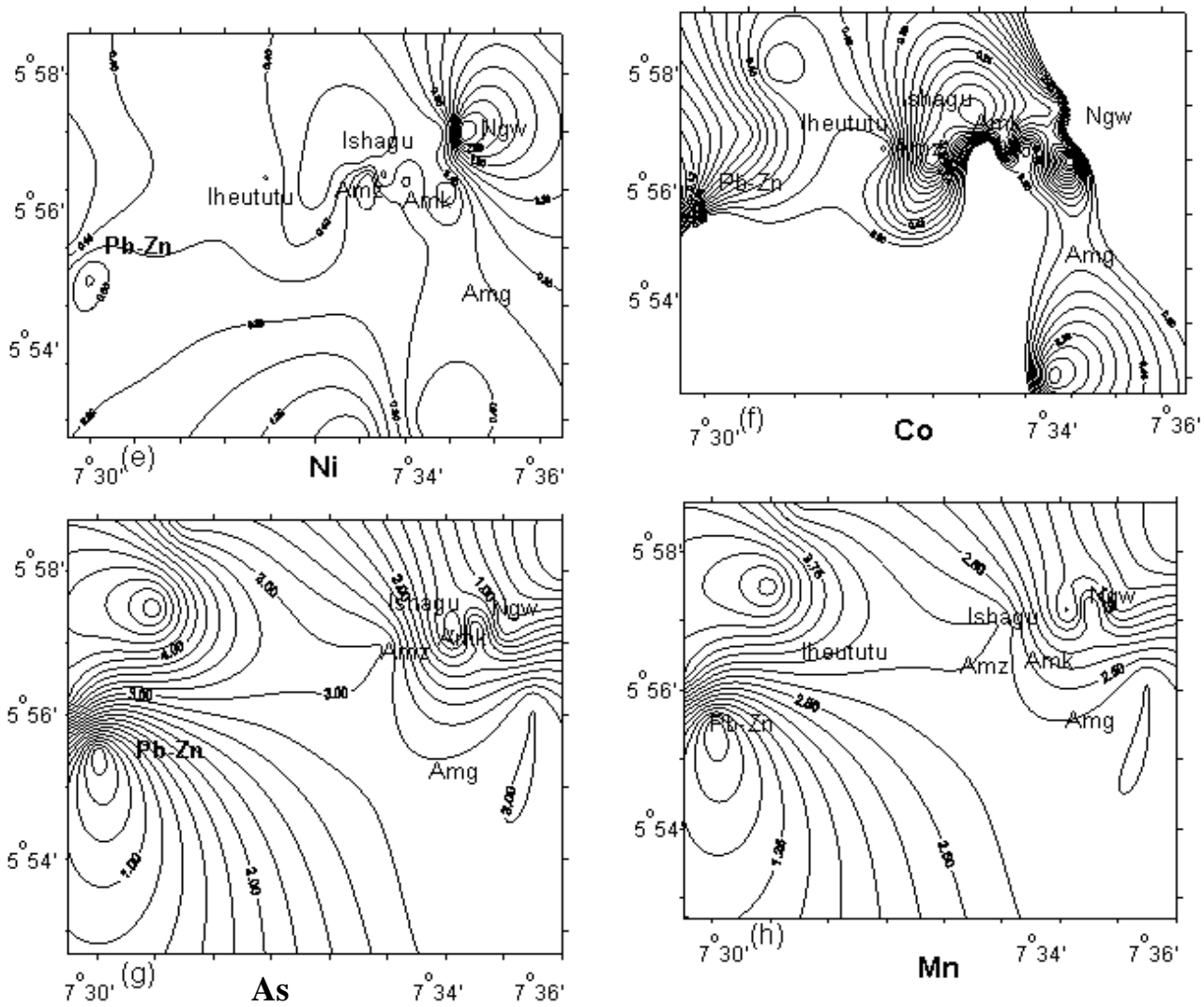

Figure 5 (e-h). Geochemical maps of some selected heavy metals in rock, soil, water and stream sediment media in Ishiagu town showing dispersion and distribution patterns of the elements. Ngw $=$ Ngwongwo, Amk $=$ Amaokwe, Amg $=$ Amagu, Amz = Amaeze

The ASE values show that there is a bit of over estimation of as value as its ASE value is higher than the corresponding RMS value. A cross-validation analysis to examine the validity of fitting models and parameters of semivariogram shows that the predictions do not deviate much from the measured values, as the RMS error and the ASE differences are minimal. 
While the MS values are closest to zero, the RMSS values are closest to 1; reflecting a good Kriging mapping surface of the contaminants' homogeneity. Kriging surfaces show significant concentrations of $\mathrm{Pb}$ (up to $3.40 \mathrm{mg} / \mathrm{l}$ ) in both the mineralized (Ikwo Iheututu) and non-mineralized zones (Amaokwe and Amaeze), and indicates that either lead is less mobile than zinc and cadmium in leachates from waste materials and/or that groundwater is seeping through some undiscovered ore deposits in Amaokwe and Amaeze areas. The low concentration of $\mathrm{Zn}$ could be attributed to low iron sulfide content, supported by near-neutral zinc - bearing seepage (Iheututu seepage) and massive presence of siderite. These align with Plant et al. (2000), Carla (2002) and Foley $(2011$, 2002) that $\mathrm{Pb}$ and cadmium generally tend to be more mobile in acid soils than in alkaline soils. In addition, near neutralization in leachates occurs from resultant effects of sulphide oxidation and calcite (Wahlstrom et al., 2009, Jiang et al., 2015). The solubility of Pb increases in an acidic environment. In the study area, the $\mathrm{pH}$ shows near neutral to alkaline environment as a result of the substantial decrease in the equilibrium carbonate concentration. Thus, the presence of calcium carbonate (Figure $6 \& 7$ ) reduces the solubility of $\mathrm{Pb}$, and, in turn, lowers its concentration levels in some areas.

The maps of geochemical distribution of heavy metals as illustrated in Figure 5 show hot spots of heavy metal contamination within Iheututu zone (close to the $\mathrm{Pb}-\mathrm{Zn}$ mine), with background shale rocks typically containing about $5.20 \mathrm{mg} / \mathrm{l} \mathrm{As}, 1.70 \mathrm{mg} / \mathrm{l} \mathrm{Pb}, 0.37 \mathrm{mg} / \mathrm{Zn}$ and $5.84 \mathrm{mg} / \mathrm{l} \mathrm{Mn}$. $\mathrm{Cu}$ and Co are evenly distributed in both zones. $\mathrm{Cd}$ and $\mathrm{Pb}$ increase towards the Iheututu zone, $\mathrm{Ni}$ and $\mathrm{Zn}$ increase towards the Ishiagu zone while Mn occurs in soil with boulders of the intrusive. In addition, the stream sediments analysis results show that $\mathrm{Cu}, \mathrm{Zn}, \mathrm{Cd}$, and $\mathrm{Pb}$ concentrations increase towards the Ishiagu zone, $\mathrm{Ni}$ is evenly distributed in both zones, while Mn is absent. Arsenic concentration is observed to be highest at Amaokwe borehole within the Ishiagu zone, containing about $5.20 \mathrm{mg} / \mathrm{l}$, indicating that As is distributed more within the mineralised zone than the non-mineralised zone.

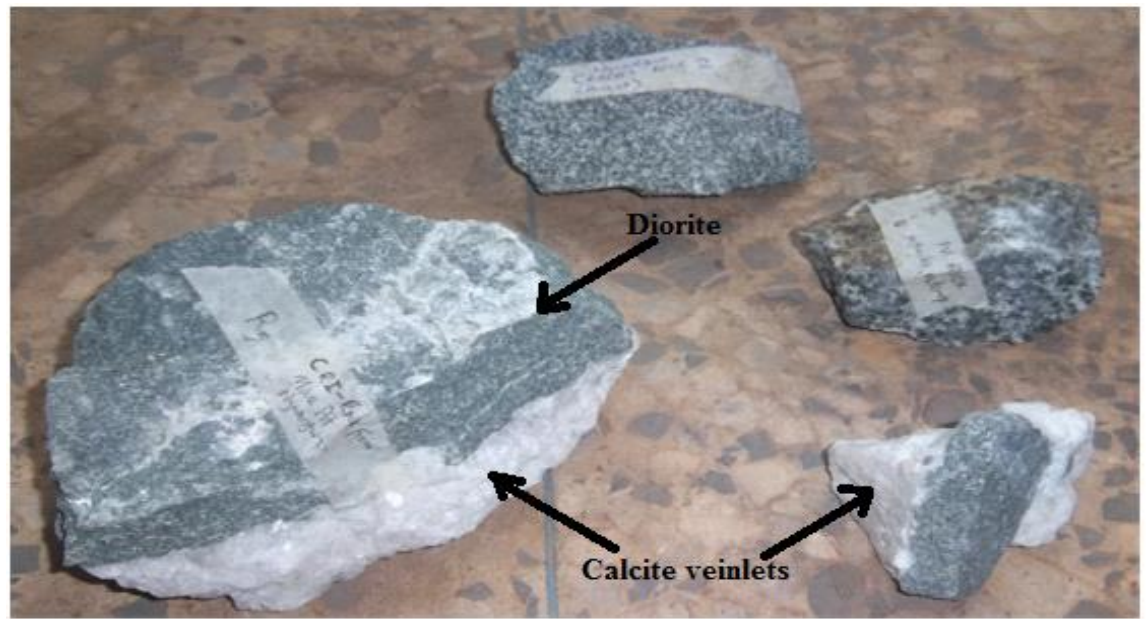

Figure 6. Rock samples from Ishiagu Crushed Rocks Industries. Arrows show calcite veinlets in diorite

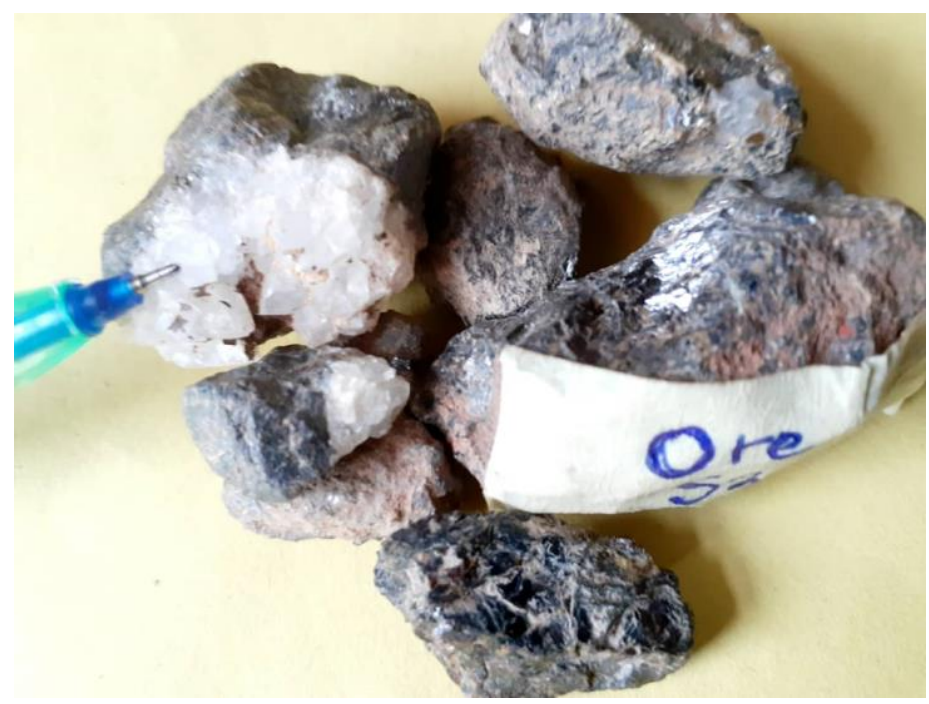

Figure 7. Ore ( $\mathrm{Pb}-\mathrm{Zn})$ tailings with carbonate mineral (calcite) from $\mathrm{Pb}-\mathrm{Zn}$ mining site at Iheututu area 


\section{Conclusions}

The analysis of the spatial distribution of $\mathrm{Pb}, \mathrm{As}, \mathrm{Cd}, \mathrm{Ni}$ and $\mathrm{Zn}$ concentrations in surface water, groundwater, stream sediment and soil in the study area showed that those at pollutant levels are $\mathrm{Pb}, \mathrm{As}, \mathrm{Cd}, \mathrm{Ni}$ and, to a lesser extent, $\mathrm{Cu}$. Their concentration levels call for remedial measures as groundwater and surface water are the only sources of potable water in the area. Water contained higher concentrations relative to the other media, and the concentrations generally increase downstream. $\mathrm{Pb}$ concentration is significantly higher in the groundwater within the Ishiagu (built up) area, even with the absence of $\mathrm{Pb}-\mathrm{Zn}$ mining activities, than in the other areas. Acidity and $\mathrm{Cu}$ concentration are also higher in this area (groundwater $\mathrm{pH}$ is up to 5 in places). It is therefore inferred that the Ishiagu area holds particularly higher unexposed and or undiscovered ore deposits that are the sources of the observed high values. Similarly, the generally high $\mathrm{Pb}$ concentration in groundwater relative to surface water in the whole study area suggests possible groundwater flow across relatively deep, unmined and or undiscovered ore deposits in the study area.

\section{Acknowledgements}

The authors are grateful to the staff of the Departments of Geological Sciences, Industrial Chemistry, Civil Engineering, and Microbiology of the Nnamdi Azikiwe University, Awka; the Department of Geology, Kogi State University Aiyagba, and the Projects Development Institute (PRODA), Enugu who were generous in providing equipment, materials and other support at various stages of this study.

\section{References}

Adebayo, A. O., Ipinmoroti, R. O., \& Ajayi, O. O. (2003). Dissolution kinetic of chalcopyrite with hydrogen peroxide in sulphuric acid medium. Chemical and Biochemical Engineering Quaterly, 17(3), 213-218.

Aroh, K. N. (2003). Acid mine drainage (AMD): Problems on potable water sources from a decommissioned mine. A case study of Ishiagu lead/zinc (Pb/Zn) mine. Institute of Geosciences and Space Technology (IGST), Rivers State University of Science and Technology, Port Harcourt, Nigeria. 105p.

Aroh, K. N., Eze, C. L., Abam, T. K. S., Gobo, A. E., \& Ubong, I. U. (2007). Physicochemical properties of pit-water from ishiagu lead/ zinc $(\mathrm{Pb} / \mathrm{Zn})$ mine as an index for alkaline classification of the mine drainage. Journal of Applied Science and Environmental Management, 11(4), 19-24.

Aroh, K. N., Ubong, I. U., Eze, C. L., \& Abam, T. K. S. (2006). Trace metal status of streams receiving acid mine drainage (AMD) from Ishiagu lead/zinc $(\mathrm{Pb} / \mathrm{Zn})$ mine, Ebonyi State, Southeast Nigeria. African Journal of Environmental Pollution and Health, 5(1), 1-8.

Babula, P., Adam, V., Opatrilova, R., Zehnalek, J., Havel, L., \& Kizek R. (2008). Uncommon heavy metals, metalloids and their plant toxicity: a review. Environmental Chemistry Letter, 6(4), p189. https://doi.org/10.1007/s10311-008-0159-9

Bohling, G. (2005). Introduction to geostatistics and variogram analysis. C\&PE 940 . http://people.ku.edu/ gbohling/geostats.

Carla, W. M. (2002). Environmental geology. Updated (5 ${ }^{\text {th }}$ ed.) Wm.C. Brown publishers, Dubugue, pp.489-505.

Carter, J. E., \& Stewart, A. G. (2000). Environmental geochemistry and health: An integrated future in medical and geochemical studies - the example of iodine. Journal of the Geological Society, London, 157, 835-836. https://doi.org/10.1144/jgs.157.4.835

Chellan, P., \& Sadler, P. J. (2015). The elements of life and medicines. Philosophical transactions. Series A, Mathematical, physical, and engineering sciences, 373(2037), 20140182. https://doi.org/10.1098/rsta.2014.0182

Chorover, J., Kretzschmar, R., Garcia-Pichel, F., \& Sparks, D. L. (2007). Soil biogeochemical processes within the critical zone. Elements, 3, 321-326. https://doi.org/10.2113/gselements.3.5.321

Cidu, R. (2002). Overview of the environmental geochemistry of mining districts in Southwestern Sardinia, Italy. Journal of Geochemistry Exploration Environment Analysis, 2, 243-251. https://doi.org/10.1144/1467-787302-028

Cidu, R. (2007). Influence of past mining on the quality of surface waters at Funtana Raminosa (Sardinia). Journal of Mine Water and the Environment, 26, 199-208. https://doi.org/10.1007/s10230-007-0013-5

Cidu, R. (2009). Abandoned mining sites: Lessons learned from hydrogeochemical studies in Sardinia. Journal of International Association of Geochemistry, 51, 11-15.

Cooksey, C. (2012). Health concerns of heavy metals and metalloids. Sci Prog., 95(1), 73-88. https://doi.org/10.3184/003685012X13286247093244

Dold, B. (2005). Basic concepts in environmental geochemistry of sulphide mine-waste. XXIV Curso Latinoamericano 
de Metalogenia UNESCO-SEG, Lima, Peru 36 p.

Edelstein, M., \& Ben-Hur, M. (2014). Heavy metals and metalloids: Sources, risks and strategies to reduce their accumulation in horticultural crops. Scientia Horticultutrae, 234, 432-444. https://doi.org/10.1016/j.scienta.2017.12.039

Egboka, B. C. E., \& Uma, K. O. (1986). Hydrogeochemistry; contaminant transport and their tectonic effects in Okposi Uburu Salt Area, Imo State, Nigeria. Hydrological Sciences Journal, 31, 205-221. https://doi.org/10.1080/02626668609491040

ESRI. (2010). ArcGIS geostatistical analyst: statistical tools for data exploration, modeling, and advanced surface generation. ESRI, New York.

Etuk, E. E., Ukpabi, N., Ukaegbu, V. U., \& Akpabio, I. O. (2008). Structural evolution, magmatism and effects of hydrocarbon maturation in Lower Benue Trough, Nigeria: A case study of Lokpaukwu, Uturu and Ishiagu. The Pacific Journal of Science and Technology, 9(2), 526-532.

Eze, C. L., \& Uko, E. D. (2003). Preliminary investigations of acid mine drainage (AMD) problems in the Ishiagu lead/zinc open-pit mine, Southeast, Nigeria. Journal of Applied Science and Environmental Management, 2, 103-109.

Eze, H. N. (2007). Environmental significance of heavy elements distribution in the Ebonyi river drainage system, Abakaliki Basin, South Eastern Nigeria. A dissertation presented to the Department of Geological Sciences, Nnamdi Azikiwe University, Awka, Nigeria.

Ezepue, M. C. (1984). The geologic setting of lead - zinc deposits at Ishiagu, Southeastern Nigeria. Journal of African Earth Sciences, 2, 97-101. https://doi.org/10.1016/S0731-7247(84)80003-8

Ezepue, M. C. (1985). Mineralogy and geochemistry of epithermal galena and siderite from Ishiagu, Southeastern Nigeria. Journal of Minning and Geology, 22(1), 137-141.

Facchinelli, A., Sacchi, E., \& Mallen, L. (2001). Multivariate statistical and GIS-based approach to identify heavy metal sources in soils. Environmental Pollution, 114(3), 313-324. https://doi.org/10.1016/S0269-7491(00)00243-8

Foley, N. K. (2002). Environmental geochemistry of platform carbonate hosted sulfide deposits. Journal of Environmental Radioactivity, chapter E, 87-100.

Foley, N. K. (2011). Carbonate-hosted lead-zinc ore deposit: last updated, 14 June, 2011.

Hajeb, P., Sloth, J. J., Shakibazadeh, S., Mahyudin, N. A., \& Afsah-Hejri, L. (2014). Toxic elements in food: occurrence, binding, and reduction approaches. Comprehensive Reviews in Food Science and Food Safety, 13(4). https://doi.org/10.1111/1541-4337.12068

Hall, J. B., \& Medler, J. A. (1975). Highland vegetation in South-Eastern Nigeria and its affinities. Vegetation, 29(3), 191-198. https://doi.org/10.1007/BF02390010

Isaaks, E. H., \& Srivastava, R. M. (1989). An introduction to applied geostatistics. Oxford University Press, 561 p.

Jiang, L., Xue, Q., \& Liu, L. (2015). Evaluation of the potential release of phosphorus from phosphate waste rock piles in different environmental scenarios. Environ Earth Sci, 74, 597. https://doi.org/10.1007/s12665-015-4063-x

Johnson, K., Hoef, J. M. V., Krivoruchko, L., \& Lucas, N. (2001). Using ArcGIS geostaistics analyst. ESRI. 380, New York Street, USA.

Kovács, E., Tamás, J., Frančišković-Bilinski, S., Omanović, D., Bilinski, H., \& Pižeta, I. (2012). Geochemical study of surface water and sediment at the abandoned $\mathrm{Pb}-\mathrm{Zn}$ mining site at Gyöngyösoroszi, Hungary. Fresenius Environmental Bulletin, 21(5a), 1212-1218.

Masi, P., \& Morgan, P. (2005). Appropriate methods for the Mean Value Test for soil contamination data-set. Land Contamination and Reclamation, 13(4). https://doi.org/10.2462/09670513.684

Mejia, L. T. (2015). Lead contamination: environmental geochemistry of gold mining villages in Northwest Nigeria. Geosciences Thesis, Department of Geosciences, Georgia State University. Retrieved from http://scholarworks.gus.edu/geosciences_theses.

Mielke, H., Gonzales, C., Smith, M., \& Mielke, P. (2000). Quantities and associations of lead, zinc, cadmium, manganese, chromium, nickel, vanadium, and copper in fresh Mississippi delta alluvium and New Orleans alluvial soils. Science of the Total Environment, 246(2-3), 249-259. https://doi.org/10.1016/S0048-9697(99)00462-3

Nigerian Geological Survey Agency (NGSA). (2010). Lead-zinc exploration opportunities in Nigeria. 
www.ngssa-ng.org.

Nwabufor-Ene, K. E. (1993). Non-oil mineral exploration. Journal of Science and Technology, ESUTH, Enugu, Nigeria, pp 15-30.

Obiorah, S. C., \& Umeji, A. C. (1995). Alkaline intrusive and extrusive rocks from areas around Ayiam River, South East Benue Trough. Journal of Mining and Geology, 31(1), 9-19.

Offodile, M. E. (1980). A mineral survey of the Cretaceous of the Benue Trough. Cretaceous Research. Academic Press, London, 1, 101-124. https://doi.org/10.1016/0195-6671(80)90020-8

Oha, I. A., Onuoha, K. M., \& Dada, S. S. (2017). Contrasting styles of lead-zinc-barium mineralization in the Lower Benue Trough, Southeastern Nigeria. Earth Sciences Research Journal, 21(1), 7-16. https://doi.org/10.15446/esrj.v21n1.39703

Okafor, G. G., \& Uwadiale, G. G. O. O. (1997). Process mineralogy of the Ishiagu lead-zinc deposit, Nigeria. Mining, Metallurgy \& Exploration, 14(4), 45-48. https://doi.org/10.1007/BF03402778

Olubambi, P. A., Ndlovu, S., Potgieter, J. H., \& Borode, J. O. (2008). Mineralogical characteristics of Ishiagu (Nigeria) complex sulfide ore. International Journal of Mineral Processing, 87, 83-89. https://doi.org/10.1016/j.minpro.2008.02.008

Onyemaobi, O. O. (1990). Flotability of Ishiagu galena as raw materials for smetters. Nigerian Journal of Applied Science, 8(1), 93-101.

Orajaka, I. P., Egboka, B. C. E., \& Emenike, E. A. (1988). Geoelectric exploration for lead-zinc sulfide deposits in Nigeria. Mining Magazine, 38-41.

Plant, J. A., Smith, B., \& Williams, L. (2000). Environmental geochemistry at global scale. Journal of Geological Society, London, 157, 837-849. https://doi.org/10.1144/jgs.157.4.837

Santelli, R. E., Cassella, R. J., Arruda, M. A. Z., \& Nobrega, J. A. (2004). Modern strategies for environmental sample preparation and analysis. In: Luiz, D. L., Ricardo, E. S., Egbert, K. D. and Jorge, J. A., (2004). Environmental geochemistry in tropical and subtropical environments. Springer-Verlag Berlin Heidelberg, New York, 37-68. https://doi.org/10.1007/978-3-662-07060-4_5

Tamás, M. J., Sharma, S. K., Ibstedt, S., Jacobson, T., \& Christen, P. (2014). Heavy metals and metalloids as a cause for protein misfolding and aggregation. Biomolecules, 4(1), 252-267. https://doi.org/10.3390/biom4010252

Thornton, I. (1983). Applied geochemistry to agriculture. In: Thornton (Ed.), Applied environmental geochemistry. Academic Press, London, $231-263 p$.

Wahlström, M., Laine-Ylijoki, J., Kaartinen, T., \& Bendz, O. H. D. (2009). Acid neutralization capacity of waste-specification of requirement stated in landfill regulations. Nordic Council of Ministers, Copenhagen, 54p. ISBN 978-92-893-1942-3Google Scholar.

WHO. (2011). Guidelines for drinking-water quality. $4^{\text {th }} \mathrm{ed}$. WHO Press, World Health Organization, 20 Avenue Appia, $1211 \quad$ Geneva 27, Switzerland. $\quad$ Retrieved from https://www.unicef.org/cholera/Chapter_4_prevention/01_WHO_Guidelines_for_drinking_water_quality.pdf

World Health Organization (WHO). (2004). Guidelines on drinking-water quality ( $3^{\text {rd }}$ ed.) incorporated $1^{\text {st }}$ and $2^{\text {nd }}$ addenda, Vol. 1 Recommendations. WHO Press, World Health Organization, Geneva, Switzerland 540p.

Zhang, C. (2006). Using multivariate analyses and GIS to identify pollutants and their spatial patterns in urban soils in Galway, Ireland. Environmental Pollution, 142, 501-511. https://doi.org/10.1016/j.envpol.2005.10.028

\section{Copyrights}

Copyright for this article is retained by the author(s), with first publication rights granted to the journal.

This is an open-access article distributed under the terms and conditions of the Creative Commons Attribution license (http://creativecommons.org/licenses/by/4.0/). 